\title{
Sand flies of Nicaragua: a checklist and reports of new collections
}

\author{
Russell W Raymond ${ }^{1 /+}$, Chad P McHugh ${ }^{2}$, Sara F Kerr ${ }^{1}$ \\ 'Department of Biology, University of the Incarnate Word, San Antonio, TX, USA \\ ${ }^{2}$ United States Air Force School of Aerospace Medicine, Brooks City-Base, TX, USA
}

Sand flies within the genus Lutzomyia serve as the vectors for all species of the protozoan parasite Leishmania in the New World. In this paper, we present a summary of the 29 species of Lutzomyia and one of Brumptomyia previously reported for Nicaragua and report results of our recent collections of 565 sand flies at eight localities in the country from 2001-2006. Lutzomyia longipalpis was the predominant species collected within the Pacific plains region of western Nicaragua, while Lutzomyia cruciata or Lutzomyia barrettoi majuscula were the species most frequently collected in the central highlands and Atlantic plains regions. The collection of Lutzomyia durani (Vargas \& Nájera) at San Jacinto in July 2001 is a new record for Nicaragua. Leishmaniasis is endemic to Nicaragua and occurs in three forms: cutaneous, mucocutaneous and visceral leishmaniasis. Cutaneous infections are the most prevalent type of leishmaniasis in Nicaragua and they occur in two different clinical manifestations, typical cutaneous leishmaniasis and atypical cutaneous leishmaniasis, depending on the species of the infecting Leishmania parasite. The distribution of sand flies collected during this study in relation to the geographic distribution of clinical forms of leishmaniasis in the country is also discussed.

Key words: Lutzomyia - Nicaragua - species checklist - Leishmania - Lutzomyia durani

In total, 29 species of Lutzomyia and one species of Brumptomyia previously have been reported for Nicaragua (Table). Our classification follows that of Young and Duncan (1994). Fairchild and Hertig (1958) made the first report of a sand fly species in Nicaragua by collecting Lutzomyia $(\mathrm{Lu}$.) vescifera from one location; however, they did not identify the location or collection date. Based on their own collections in 1953 and material provided by others, Fairchild and Hertig (1959) documented the presence of 11 additional named species and three unnamed species in Nicaragua. One of the unidentified species was later determined to be Lutzomyia serrana, while the remaining two were described as new species Lutzomyia odax and Lutzomyia dasymera (Fairchild \& Hertig 1961a). Fairchild and Hertig (1961b) described Lutzomyia nicaraguensis from specimens collected in the south-central region east of Lake Nicaragua and Young (1979) later reduced this to a subspecies of Lutzomyia hirsuta. Young (1979) reexamined the paratype of Lutzomyia barrettoi collected by Fairchild and Hertig (1959) and gave subspecific status as Lutzomyia barrettoi majuscula based on morphologic differences among specimens from Central America and those from South America and Trinidad.

Zeledón and Murillo (1983) reported collecting several species, including five new records from extreme southcentral Nicaragua near the border with Costa Rica. Le Pont et al. (1987) described the female Lutzomyia zeledoni from material collected on the Pacific plain of Nicaragua and re-

Financial support: NIH (GM 55337-07)

+ Corresponding author: raymond@uiwtx.edu

Received 4 May 2010

Accepted 12 August 2010 ported Lutzomyia longipalpis to be common at many sites in the northwest and central regions of the country.

The literature on Latin American and Caribbean phlebotomines through 1993 was catalogued by Young and Duncan (1994). Based on published reports and their examination of additional specimens, they concluded that 20 species and subspecies of Lutzomyia occur in Nicaragua. They questioned the report of Lutzomyia geniculata by Zeledón and Murillo (1983) because that record was based solely on females that are indistinguishable from Lutzomyia corossoniensis and Lutzomyia guyanensis. Valle and Rivera (1995) collected specimens for 18 months at 16 locations and documented the presence of three previously unrecorded species of Lutzomyia and the first record of a Brumptomyia, Brumptomyia galindoi, in Nicaragua. Their report of Lutzomyia trapidoi as a new record was incorrect; it was previously collected by Zeledón and Murillo (1983). Le Pont et al. (1995) described both male and female Lutzomyia legerae from specimens collected in central Nicaragua. Collantes and Martinez-Ortega (1998) collected sand flies at 10 locations in Nicaragua during 1995. They found 10 species, including males and females of Lu. geniculata and new records for Lutzomyia caprina and Lutzomyia camposi.

We report recent collections from eight localities, including the collection of Lutzomyia durani (Vargas \& Nájera 1952), a new record for Nicaragua.

\section{MATERIALS AND METHODS}

Nicaragua is located in the center of the Central American Isthmus and is bordered by Honduras to the north and Costa Rica to the south. It is bounded by the Caribbean Sea to the east and the Pacific Ocean to the west. The country consists of three general physiographic regions (Figure); the Pacific plains, the central highlands and the Atlantic lowland plains (Taylor 1963). 
TABLE

Checklist of phlebotomine sand flies reported from Nicaragua in accordance with the year of first collection and the reference

\begin{tabular}{|c|c|c|}
\hline Species & Year first collected & Reference \\
\hline $\begin{array}{l}\text { Lutzomyia aclydifera } \\
\text { (Fairchild \& Hertig 1952) }\end{array}$ & 1953 & Fairchild and Hertig (1959) \\
\hline $\begin{array}{l}\text { Lutzomyia barrettoi } \\
\text { (Mangabeira 1942) }\end{array}$ & $1953^{a}$ & Fairchild and Hertig (1959) \\
\hline $\begin{array}{l}\text { Lutzomyia bispinosa } \\
\text { (Fairchild \& Hertig 1951) }\end{array}$ & 1953 & Fairchild and Hertig (1959) \\
\hline $\begin{array}{l}\text { Lutzomyia cruciata } \\
\text { (Coquillett 1907) }\end{array}$ & 1953 & Fairchild and Hertig (1959) \\
\hline $\begin{array}{l}\text { Lutzomyia evansi } \\
\text { (Nuñez-Tovar 1924) }\end{array}$ & 1953 & Fairchild and Hertig (1959) \\
\hline $\begin{array}{l}\text { Lutzomyia gomezi } \\
\text { (Nitzulescu 1931) }\end{array}$ & 1953 & Fairchild and Hertig (1959) \\
\hline $\begin{array}{l}\text { Lutzomyia ovallesi } \\
\text { (Ortiz 1952) }\end{array}$ & 1953 & Fairchild and Hertig (1959) \\
\hline $\begin{array}{l}\text { Lutzomyia panamensis } \\
\text { (Shannon 1926) }\end{array}$ & 1953 & Fairchild and Hertig (1959) \\
\hline $\begin{array}{l}\text { Lutzomyia shannoni } \\
\text { (Dyar 1929) }\end{array}$ & 1953 & Fairchild and Hertig (1959) \\
\hline $\begin{array}{l}\text { Lutzomyia trinidadensis } \\
\text { (Newstead 1922) }\end{array}$ & 1953 & Fairchild and Hertig (1959) \\
\hline $\begin{array}{l}\text { Lutzomyia vesicifera } \\
\text { (Fairchild \& Hertig 1947) }\end{array}$ & $1953^{b}$ & Fairchild and Hertig (1959) \\
\hline $\begin{array}{l}\text { Lutzomyia ylephiletor } \\
\text { (Fairchild \& Hertig 1952) }\end{array}$ & 1953 & Fairchild and Hertig (1959) \\
\hline $\begin{array}{l}\text { Lutzomyia dasymera } \\
\text { (Fairchild \& Hertig 1961) }\end{array}$ & 1953 & Fairchild and Hertig (1961a) \\
\hline $\begin{array}{l}\text { Lutzomyia odax } \\
\text { (Fairchild \& Hertig 1961) }\end{array}$ & 1953 & Fairchild and Hertig (1961a) \\
\hline $\begin{array}{l}\text { Lutzomyia serrana } \\
\text { (Damasceno \& Arouck 1949) }\end{array}$ & 1953 & Fairchild and Hertig (1961a) \\
\hline $\begin{array}{l}\text { Lutzomyia nicaraguensis } \\
\text { (Fairchild \& Hertig 1961) }\end{array}$ & 1953 & Fairchild and Hertig (1961b) \\
\hline $\begin{array}{l}\text { Lutzomyia geniculata } \\
\text { (Mangabeira 1941) }\end{array}$ & $1977^{c}$ & Zeledón and Murillo (1983) \\
\hline $\begin{array}{l}\text { Lutzomyia olmeca } \\
\text { (Vargas \& Nájera 1959) }\end{array}$ & 1977 & Zeledón and Murillo (1983) \\
\hline $\begin{array}{l}\text { Lutzomyia sanquinaria } \\
\text { (Fairchild \& Hertig 1957) }\end{array}$ & 1977 & Zeledón and Murillo (1983) \\
\hline $\begin{array}{l}\text { Lutzomyia trapidoi } \\
\text { (Fairchild \& Hertig 1952) }\end{array}$ & 1977 & Zeledón and Murillo (1983) \\
\hline $\begin{array}{l}\text { Lutzomyia vespertilionis } \\
\text { (Fairchild \& Hertig 1947) }\end{array}$ & 1977 & Zeledón and Murillo (1983) \\
\hline $\begin{array}{l}\text { Lutzomyia legerae } \\
\text { (Gantier 1995, Hue \& Valle 1995, Le Pont 1995) }\end{array}$ & 1986 & Le Pont et al. (1995) \\
\hline $\begin{array}{l}\text { Lutzomyia longipalpis } \\
\text { (Lutz \& Neiva 1912) }\end{array}$ & $1987^{d}$ & Le Pont et al. (1987) \\
\hline $\begin{array}{l}\text { Lutzomyia zeledoni } \\
\text { (Young \& Murillo 1984) }\end{array}$ & $1987^{d}$ & Le Pont (1987) \\
\hline
\end{tabular}




\begin{tabular}{|c|c|c|}
\hline Species & Year first collected & Reference \\
\hline $\begin{array}{l}\text { Brumptomyia galindoi } \\
\text { (Fairchild \& Hertig 1947) }\end{array}$ & $1988-1994^{e}$ & Valle and Rivera (1995) \\
\hline $\begin{array}{l}\text { Lutzomyia carpenteri } \\
\text { (Fairchild \& Hertig 1953) }\end{array}$ & $1988-1994^{e}$ & Valle and Rivera (1995) \\
\hline $\begin{array}{l}\text { Lutzomyia cayennensis } \\
\text { (Floch \& Abonnenc 1941) }\end{array}$ & $1988-1994^{e}$ & Valle and Rivera (1995) \\
\hline $\begin{array}{l}\text { Lutzomyia chiapanensis } \\
\text { (Dampf 1947) }\end{array}$ & $1988-1994^{e}$ & Valle and Rivera (1995) \\
\hline $\begin{array}{l}\text { Lutzomyia camposi } \\
\text { (Rodriguez 1952) }\end{array}$ & 1995 & Collantes and Martinez-Ortega (1998) \\
\hline $\begin{array}{l}\text { Lutzomyia caprina } \\
\text { (Morales \& Osorno 1972, Osorno-Mesa 1972) }\end{array}$ & 1995 & Collantes and Martinez-Ortega (1998) \\
\hline $\begin{array}{l}\text { Lutzomyia durani } \\
\text { (Vargas \& Nájera 1952) }\end{array}$ & 2001 & New record \\
\hline
\end{tabular}

$a$ : Young (1979) designated as subspecies Lutzomyia barrettoi majuscula upon re-examination; $b$ : Lu. vesicifera was first reported in Fairchild and Hertig (1958) without a specific year [Fairchild and Hertig (1959) indicated the collection year as 1953]; $c$ : only females were collected, no males for identification; $d$ : publication date, no collection date given; $e$ : inclusive dates of collections, no specific year given.

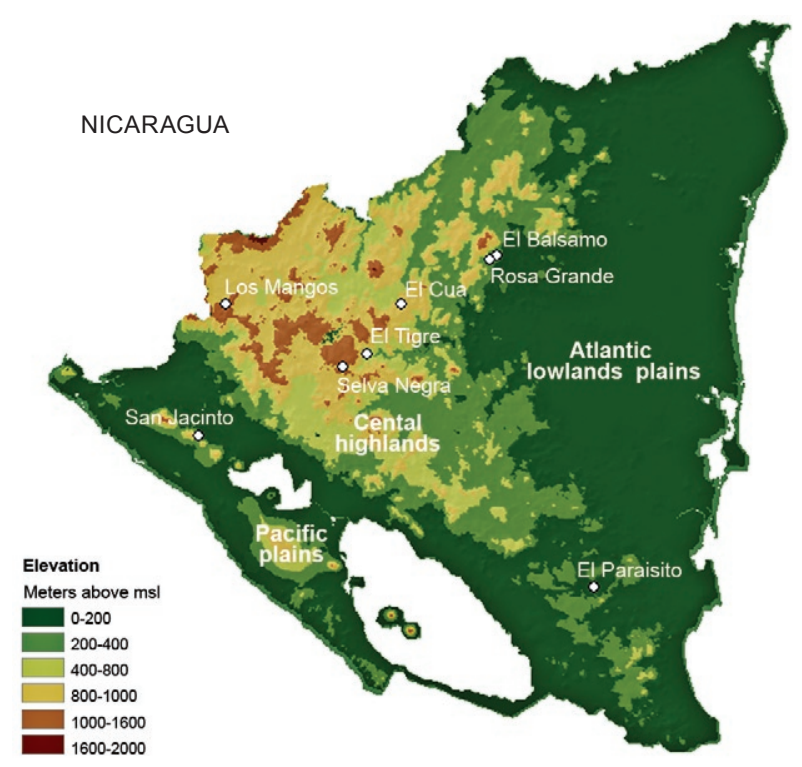

Locations of sand fly collection sites, 2001-2006, and the three general physiographic regions of Nicaragua as described by Taylor (1963). msl: mean sea level.

The Pacific plains region is characterized by mean annual temperatures of $25.5-27.5^{\circ} \mathrm{C}$. It has a mean annual rainfall of 1000-1800 $\mathrm{mm}$ with distinct wet (June-November) and dry (December-May) seasons. Elevations predominantly range from sea level to approximately $200 \mathrm{~m}$ above mean sea level (msl); however, a series of volcanoes is located on a roughly north-south line through the centre of this region with elevations up to $1600 \mathrm{~m}$ above msl. The soils of the Pacific plains are sandy or sandy-loam to loam, with areas of clay soils scattered throughout (Taylor 1963, MARENA 2004). This region is the most populous and has extensive agricultural usage. The natural vegetation consists primarily of deciduous forest or deciduous shrubs covering less than $25 \%$ of the area. We collected at one site, San Jacinto, in this region.

San Jacinto $\left(12^{\circ} 35^{\prime} \mathrm{N}, 086^{\circ} 45^{\prime} \mathrm{W}\right)$ is located within the municipality of Telica in the department of Leon. The elevation is approximately $175 \mathrm{~m}$ above $\mathrm{msl}$ and the area has an annual rainfall of $1400-1600 \mathrm{~mm}$. The mean annual temperature is $26.5^{\circ} \mathrm{C}$ and the soil is sandy-loam (MARENA 2004). The habitat is primarily characterized by deciduous shrubs with scattered trees. Collections were made in July and August 2001, January 2002 and August 2004.

The central highlands have mean annual temperatures ranging from $18.5-24.5^{\circ} \mathrm{C}$. This is the driest region in the country with a mean annual rainfall of 800-1600 mm (Taylor 1963, MARENA 2004). The region also has distinct wet and dry seasons with the dry season generally shorter than that of the Pacific plains, averaging approximately four months. The region is characterized by the Segoviana, Isabelia and Dariense mountain ranges with elevations varying from $600-2000 \mathrm{~m}$ above msl. The soils in the western portion of the region are predominantly clay-loam, while clay soils dominate the eastern two-thirds of the region (MARENA 2004). Land use is extremely varied, ranging from areas of extensive agriculture usage to relatively undisturbed seasonal evergreen rainforest and lower montane tropical forest. We collected at five sites in this region.

El Cua $\left(13^{\circ} 20^{\prime} \mathrm{N}, 085^{\circ} 39^{\prime} \mathrm{W}\right)$ is located within the municipality of Cua-Bocay in the Department of Jinotega. This area is mountainous and elevations at the site range from $700-800 \mathrm{~m}$ above $\mathrm{msl}$. The annual rainfall is 1400 - 
$1600 \mathrm{~mm}$ and the mean annual temperature is $23.5^{\circ} \mathrm{C}$. The soil is clay (MARENA 2004). Collection sites were located near the edges of coffee and bean fields and were sampled in March 2006.

El Tigre $\left(13^{\circ} 04^{\prime} \mathrm{N}, 085^{\circ} 45^{\prime} \mathrm{W}\right)$ is in the municipality of El Tuma-La Dalia, Department of Matagalpa. This collection site is approximately $450 \mathrm{~m}$ above msl. The mean annual rainfall is $1200-1400 \mathrm{~mm}$ and the mean annual temperature is $24.5^{\circ} \mathrm{C}$ (MARENA 2004). The soils are predominantly clay and the area consists of small farms with scattered trees primarily along hedgerows and riverbanks. Collections were made in May 2002.

Los Mangos $\left(13^{\circ} 26^{\prime} \mathrm{N}, 086^{\circ} 35^{\prime} \mathrm{W}\right)$ is in the Northwestern central highlands near the border with Honduras in the municipality of San Lucas, Department of Madriz. The collection site is at approximately $980 \mathrm{~m}$ above msl. The mean annual rainfall is $1000-1200 \mathrm{~mm}$ and the mean annual temperature is $22.5^{\circ} \mathrm{C}$. The soils are predominately clay with large rocks scattered throughout (MARENA 2004). This terrain is very rugged and mountainous and the collection sites were located in an area of scattered evergreen pines and deciduous oaks with small hillside farms. Collections were made in January 2002.

Selva Negra $\left(12^{\circ} 59^{\prime} \mathrm{N}, 085^{\circ} 54^{\prime} \mathrm{W}\right)$ is in the Northeast area of the municipality and Department of Matagalpa. The site is quite mountainous with elevations from 1200$1600 \mathrm{~m}$ above msl. The mean annual rainfall is $1200-$ $1400 \mathrm{~mm}$ and the mean annual temperature is $20.5^{\circ} \mathrm{C}$ (MARENA 2004). The area is submontane evergreen tropical forest with scattered coffee plantations. Collections were made in May 2002 and May 2003.

The Atlantic lowland plains has a mean annual temperature of $26.5^{\circ} \mathrm{C}$ and is the wettest region in Nicaragua with annual rainfall of $1800 \mathrm{~mm}$ to greater than $4000 \mathrm{~mm}$, with areas near the coast receiving the most rain (Taylor 1963). There are distinct wet and dry seasons, with the dry season being relatively short, lasting approximately three months from February-April (Taylor 1963). Elevations throughout the region primarily range from sea level to $200 \mathrm{~m}$ above msl. However, the very southern extreme of the mountain ranges that run through the centre of the country extend into the Atlantic lowland plains with altitudes in some areas up to $600 \mathrm{~m}$ above msl. Land use varies considerably with areas of extensive agriculture and $10-15 \%$ natural vegetation coverage, to areas dominated by dense tropical evergreen forest (Taylor 1963, MARENA 2004). This region has seen a great amount of timber harvesting and conversion from forest to farmland in the last 25 years (MARENA 2004). Three sites were sampled in this area.

El Paraisito $\left(11^{\circ} 41^{\prime} \mathrm{N}, 084^{\circ} 24^{\prime} \mathrm{W}\right)$ is in the municipality of Nueva Guinea in the South Atlantic Autonomous Region at an elevation of approximately $200 \mathrm{~m}$ above $\mathrm{msl}$. The mean annual rainfall is $2000-2400 \mathrm{~mm}$ and the mean annual temperature is $26.5^{\circ} \mathrm{C}$ (MARENA 2004). The soils are predominately brown clay. Much of the area is dotted with cattle ranches and dairy farms with large trees scattered along hedgerows and riverbanks. Collections were made in May and June 2004 and March, May and June 2005.
El Balsamo (13⒊' $\left.\mathrm{N}, 084^{\circ} 58^{\prime} \mathrm{W}\right)$ and Rosa Grande $\left(13^{\circ} 38^{\prime} \mathrm{N}, 085^{\circ} 08^{\prime \prime} \mathrm{W}\right)$ are located in the municipality of Siuna in the North Atlantic Autonomous Region with the elevation at both localities about $300 \mathrm{~m}$ above msl. Mean annual rainfall at the locations is $1400-1600 \mathrm{~mm}$ and the mean annual temperature is $25.5^{\circ} \mathrm{C}$. The soils in the area are predominately reddish clay. These areas are classified as subtropical wet forest but have extensive agricultural systems with $25-50 \%$ natural vegetation coverage (MARENA 2004). Collections were made in May and July 2003 and May 2004.

Sand flies were collected using Model 1012 New Standard Miniature Light Traps (John W Hock Co, Gainesville, FL, USA) placed in and around residences where human cases of leishmaniasis had been reported. Specimens were killed by placing the collection containers in a freezer overnight. Sand flies were removed and placed in Petri dishes between two pieces of tissue paper for transport and later cleared and identified using the guide of Young and Duncan (1994).

\section{RESULTS}

Between August 2001-March 2006, a total of 565 sand flies were collected at the eight localities. Five hundred eighteen were identified to the species level, eight to the subgenus level, seven to the group level and 32 only as Lutzomyia species.

At San Jacinto, 440 sand flies were collected (Table I, Supplementary data). Lu. durani previously was collected in Honduras and El Salvador (Rosabal \& Trejos 1964, Navin et al. 1985). Our collections of Lu. durani represent a new record for Nicaragua.

Two flies were collected at El Cua in March 2006, one male Lutzomyia panamensis and one male Lutzomyia cruciata.

A total of 27 flies were captured at El Tigre in May of 2002, 20 male and four female Lu. cruciata and three male $\mathrm{Lu}$. longipalpis.

A total of 43 flies were collected at Los Mangos in January 2002, 19 male and 23 female Lu. cruciata and one female Lu. longipalpis.

Selva Negra produced only four specimens from May 2002-May 2003, all of which could only be identified as females in the genus Lutzomyia.

From May 2004-June 2005, a total of 23 sand flies were collected at El Paraisito, only 11 of which could be given specific identification (Table II, Supplementary data). The single male in the subgenus Helcocyrtomyia may have been Lutzomyia sanguinaria, which is known to occur in southern Nicaragua, or Lutzomyia hartmanni, which would be a new record for Nicaragua, but which has been found across the border in Costa Rica (Murillo \& Zeledón 1985). The single male and four females identified only as subgenus Nyssomyia may have been Lutzomyia ylephiletor, which has been collected previously in Nicaragua, or Lutzomyia edentula, which occurs to the north in Honduras and the south in Costa Rica (Young \& Duncan 1994).

At El Balsamo and Rosa Grande a total of 26 sand flies were captured during May-July 2003 and May 2004 , only 12 of which were identified to the species 
level (Table III, Supplementary data). Seven were identified to the group level, one to the subgenus level and six only to Lutzomyia species.

\section{DISCUSSION}

The distribution of sand flies in our study corresponds closely with the distribution of cases of human leishmaniasis in Nicaragua, of which there are three types: mucocutaneous (MCL), visceral (VL) and cutaneous (CL) (Missoni et al. 1986, Darce et al. 1991, Belli et al. 1994, 1999). MCL and VL are relatively uncommon while $\mathrm{CL}$ occurs with considerable frequency. $\mathrm{CL}$ occurs in two clinical presentations; typical CL is characterized by open skin lesions and is the predominant form in the central highlands and Atlantic lowland plains and atypical CL is characterized by non-ulcerative lesions and is common in the Pacific plains. Parasites isolated from cases of typical CL have been reported to be Leishmania braziliensis and Leishmania panamensis and those from atypical CL as Leishmania chagasi (Missoni et al. 1986, Darce et al. 1991, Belli et al. 1994, 1998, 1999). In Nicaragua, approximately 2,000-2,500 cases of CL are reported annually with approximately $86 \%$ of these diagnosed as typical CL (MINSA 2003).

Lu. longipalpis and Lutzomyia evansi were the most commonly collected species on the Pacific plains. This is generally consistent with reports of others (Fairchild \& Hertig 1959,Zeledón \& Murillo 1983, Valle \& Rivera 1995) and is significant because they are vectors of $L$. chagasi (Lainson et al. 1977, Killick-Kendrick 1999), the etiologic agent of VL and atypical CL in the New World. L. chagasi has been isolated from patients with VL and atypical $\mathrm{CL}$ in Nicaragua. While L. chagasi has not been isolated from either sand fly species in Nicaragua, the geographic distribution of VL and atypical CL in Nicaragua closely corresponds to the distribution of $L u$. longipalpis and $L u$. evansi and suggests they are the most likely vectors of $L$. chagasi in the country. Although the vast majority of $L u$. longipalpis collected during this study were from the $\mathrm{Pa}$ cific plains, we did collect three specimens from El Tigre, extending its known range into the central highlands.

Lu. evansi, Lutzomyia cayennensis, Lutzomyia chiapanensis, Lutzomyia vesicifera, Lutzomyia gomezi, $L u$. zeledoni and $L u$. durani were collected by us only in the Pacific plains region. This generally supports the results of previous researchers in Nicaragua. Valle and Rivera (1995) found $L u$. evansi to be the most abundant species in the Pacific plains and Fairchild and Hertig (1959) only collected that species in the Pacific plains region. Lu. cayennensis and all but one Lu. chiapanensis were collected by Valle and Rivera (1995) in the Pacific plains. $L u$. vesicifera has previously been collected in all regions of Nicaragua, but was most common in the Pacific plains (Fairchild \& Hertig 1959, Zeledón \& Murillo 1983, Valle \& Rivera 1995). Lu. gomezi was also collected in low numbers in all regions of the country (Fairchild \& Hertig 1959, Zeledón \& Murillo 1983, Valle \& Rivera 1995).

$L u$. cruciata also was collected with some success in the Pacific plains in contrast to the report of Valle and Rivera (1995), who collected over 2,000 Lu. cruciata in the central highlands, mostly in the region around Matagalpa and the Atlantic plains, but only collected four in the Pacific plains.

In the central highlands and Atlantic lowland plains where typical CL is the predominant form of leishmaniasis (Missoni et al. 1986, Belli et al. 1999), the most commonly collected species were $L u$. cruciata and $L u$. barrettoi majuscula. Although Lu. cruciata has not been shown to be a vector of Leishmania in Nicaragua, it is anthropophilic and has been associated with areas of typical CL in other areas of the New World. Lu. cruciata has been found to be naturally infected with leishmanial parasites (Young \& Duncan 1994, Rebollar-Téllez et al. 1996a, b) and is capable of transmitting Leishmania mexicana under experimental conditions (Williams 1966).

In our study, Lu. barrettoi majuscula, Lutzomyia shannoni and Lu. panamensis were only collected in the central highlands or Atlantic plains. Fairchild and Hertig (1959) collected Lu. barrettoi near Managua in the Pacific plains and Valle and Rivera (1995) collected it only in the central highlands and the northern areas of the Atlantic plains. We collected this species in El Paraisito, extending the known range into the southern Atlantic plains. Although we collected Lu. shannoni only at El Balsamo, it has previously been found in all regions of the country (Fairchild \& Hertig 1959, Zeledón \& Murillo 1983, Valle \& Rivera 1995).

We collected Lu. panamensis from El Cua in the central highlands and El Balsamo and Rosa Grande in the northern region of the Atlantic lowlands. Previous studies identified its range throughout most of the central highlands and Atlantic lowland plains, but not the Pacific plains (Fairchild \& Hertig 1959, Zeledón \& Murillo 1983, Valle \& Rivera 1995). This species is a suspected vector of L. mexicana, L. braziliensis and L. panamensis, the etiologic agents of typical CL (Christensen et al. 1983, Killick-Kendrick 1999) and its distribution corresponds with the known distribution of typical CL in Nicaragua.

\section{ACKNOWLEDGEMENTS}

To the Nicaraguan Ministerio de Salud (MINSA), for access to trapping localities, laboratory space and field assistance, to the Ministerio del Ambiente y los Recursos Naturales (MARENA), for climate and ecological data, to Dr David Young and Dr MV Herrero, for assistance with sand fly identification, to Eboniece Cason, for data compilation, to the communities of El Balsamo, El Cua, El Tigre, El Paraisito, Los Mangos, Nueva Guinea, Rosa Grande and San Jacinto and to the staff at Selva Negra.

\section{REFERENCES}

Belli A, García D, Palacios X, Rodriguez B, Valle S, Videa E, Tinoca E, Marín F, Harris E 1999. Widespread atypical cutaneous leishmaniasis caused by Leishmania (L.) chagasi in Nicaragua. Am J Trop Med Hyg 61: 380-385.

Belli A, Miles MA, Kelly JM 1994. A putative Leishmania panamensis/Leishmania braziliensis hybrid is a causative agent of human cutaneous leishmaniasis in Nicaragua. Parasitology 109: 435-442.

Belli A, Rodriguez B, Aviles H, Harris E 1998. Simplified polymerase chain reaction detection of New World Leishmania in clinical specimens of cutaneous leishmaniasis. Am J Trop Med Hyg 58: 102-109. 
Christensen HA, Fairchild GB, Herrer A, Johnson CM, Young DG, de Vásquez AM 1983. The ecology of cutaneous leishmaniasis in the Republic of Panama. J Med Entomol 20: 463-484.

Collantes F, Martinez-Ortega E 1998. New records of phlebotomine sand flies (Diptera: Psychodidae) from Nicaragua. Rev Nica Entomol 41: 27-30.

Darce M, Moran J, Palacios X, Belli A, Gomez-Urcuyo F, Zamora D, Valle S, Gantier JC, Momen H, Grimaldi Júnior G 1991. Etiology of human cutaneous leishmaniasis in Nicaragua. Trans $R$ Soc Trop Med Hyg 85: 58-59.

Fairchild GB, Hertig M 1958. Notes on the Phlebotomus of Panama. XIV. (Diptera, Psychodidae) P. vespertilionis and related species. Ann Entomol Soc Am 51: 509-516.

Fairchild GB, Hertig M 1959. Geographic distribution of the Phlebotomus sandflies of Central America (Diptera: Psychodidae). Ann Entomol Soc Am 52: 121-124.

Fairchild GB, Hertig M 1961a. Notes on the Phlebotomus of Panama. XVI. (Diptera, Psychodidae). Descriptions of new and littleknown species from Panama and Central America. Ann Entomol Soc Am 54: 237-255.

Fairchild GB, Hertig M 1961b. Three new species of Phlebotomus from Mexico and Nicaragua (Diptera: Psychodidae). Proc Entomol Soc Wash 63: 22-28.

Killick-Kendrick R 1999. The biology and control of phlebotomine sand flies. Clin Dermatol 17: 279-289.

Lainson R, Ward RD, Shaw JJ 1977. Experimental transmission of Leishmania chagasi, causative agent of neotropical visceral leishmaniasis by the sand fly Lutzomyia longipalpis. Nature 226: 628-630.

Le Pont F, Desjeux P, Gonzales A 1987. Phlébotomes du Nicaragua. I. Description de la femelle de Lutzomyia zeledoni Young et Murillo, 1984 (Diptera, Psychodidae), et implication épidemiologique de la présence de Lutzomyia longipalpis sur la façade Pacifique. Mem Inst Oswaldo Cruz 82: 273-276.

Le Pont F, Gantier JC, Hue S, Valle S 1995. Phlébotomes du Nicaragua. II. Description de Lutzomyia legerae n. sp. (Diptera: Pyschodidae). Parasite 2: 75-79.

MARENA - Ministerio del Ambiente y los Recursos Naturales 2004. Atlas Forestal, 1st ed., MARENA, Managua, 55 pp.
MINSA - Ministerio de Salud Nicaragua 2003. Situación epidemiologica de la leishmaniasis en Nicaragua. Boletin Epidemiologica 37: 1-4.

Missoni E, Morelli R, Balladares L, Berrios J, de Solan MD, Baldwin CI, Evans DA 1986. Isolation and characterization of leishmaniasis from Nicaragua. Trans R Soc Trop Med Hyg 80: 999-1000.

Murillo J, Zeledón R 1985. Flebótomos de Costa Rica. Brenesia 23 (Suppl. 1): 1-137.

Navin TR, Sierra M, Custodio R, Steurer F, Porter CH, Ruebush TK 2nd 1985. Epidemiologic study of visceral leishmaniasis in Honduras, 1975-1983. Am J Trop Med Hyg 34: 1069-1075.

Rebollar-Téllez EA, Ramírez-Fraire A, Andrade-Narvaez FJ 1996a. A two years study on vectors of cutaneous leishmaniasis. Evidence for sylvatic transmission cycle in the state of Campeche, Mexico. Mem Inst Oswaldo Cruz 91: 555-560.

Rebollar-Téllez EA, Reyes-Villanueva F, Fernandez-Salas I, AndradeNarvaez FJ 1996b. Abundance and parity rate of Lutzomyia cruciata (Diptera: Psychodidae) in an endemic focus of localized cutaneous leishmaniasis in southern Mexico. J Med Entomol 33: 683-685.

Rosabal R, Trejos A 1964. Phlebotomus de El Salvador (Diptera, Psychodidae). I. Especies conocidas. Rev Biol Trop 12: 167-173.

Taylor BW 1963. An outline of the vegetation of Nicaragua. $J$ Ecol 51: $27-54$.

Valle S, Rivera P 1995. Dispersión de las especies de Lutzomyia y Brumptomyia (Diptera: Psychodidae) en Nicaragua. Rev Nica Entomol 32: 19-27.

Williams P 1966. Experimental transmission of Leishmania mexicana by Lutzomyia cruciata. Ann Trop Med Parasitol 60: 365-372.

Young DG 1979. A review of the bloodsucking psychodid flies of Colombia (Diptera: Phlebotominae and Sycoracinae), Technical Bulletin 806, Institute of Food and Agricultural Sciences/University of Florida, Gainesville, $266 \mathrm{pp}$.

Young DG, Duncan MA 1994. Guide to the identification and geographic distribution of Lutzomyia sandflies in Mexico, the West Indies, Central and South America (Diptera: Psychodidae), Associated Publishers, American Entomology Institute, Gainsville, 881 pp.

Zeledón R, Murillo J 1983. Anthropophilic sandflies of Nicaragua, Central America. Trans R Soc Trop Med Hyg 77: 280. 
TABLE I

Sand flies collected at San Jacinto, Nicaragua, 2001-2004

\begin{tabular}{|c|c|c|c|c|c|}
\hline & $\begin{array}{l}\text { July } \\
2001\end{array}$ & $\begin{array}{c}\text { August } \\
2001\end{array}$ & $\begin{array}{c}\text { January } \\
2002\end{array}$ & $\begin{array}{c}\text { August } \\
2004\end{array}$ & Total \\
\hline & diq & J/o & J/q & J/q & olq \\
\hline Lutzomyia cayennensis & $1 /-$ & $-/-$ & $-/-$ & $-/-$ & $1 / 0$ \\
\hline Lutzomyia chiapanensis & $5 / 14$ & $2 / 5$ & $-/-$ & $-/-$ & $7 / 19$ \\
\hline Lutzomyia cruciata & $-/-$ & $-/ 9$ & $3 / 2$ & $-/-$ & $3 / 11$ \\
\hline Lutzomyia durani & $1 / 2$ & $-/-$ & $-/-$ & $-/-$ & $1 / 2$ \\
\hline Lutzomyia evansi & $38 / 8$ & $11 / 8$ & $13 / 17$ & $-/-$ & $62 / 33$ \\
\hline Lutzomyia gomezi & $1 /-$ & $-/-$ & $1 / 1$ & $-/-$ & $2 / 1$ \\
\hline Lutzomyia longipalpis & $60 / 27$ & $42 / 12$ & $109 / 22$ & $-/-$ & $211 / 61$ \\
\hline Lutzomyia vesicifera & $-/ 6$ & $-/ 1$ & $-/-$ & $-/-$ & $0 / 7$ \\
\hline Lutzomyia zeledoni & $-/-$ & $-/-$ & $-/ 2$ & $-/-$ & $0 / 2$ \\
\hline Lutzomyia spp & $2 / 11$ & $-/ 3$ & $-/-$ & $1 /-$ & $3 / 14$ \\
\hline Total & $108 / 68$ & $55 / 38$ & $126 / 44$ & $1 / 0$ & $290 / 150$ \\
\hline
\end{tabular}

TABLE II

Sand flies collected at El Paraisito, Nicaragua, 2004-2005

\begin{tabular}{|c|c|c|c|c|c|c|}
\hline & $\begin{array}{l}\text { May } \\
2004\end{array}$ & $\begin{array}{l}\text { June } \\
2004\end{array}$ & $\begin{array}{c}\text { March } \\
2005\end{array}$ & $\begin{array}{l}\text { May } \\
2005\end{array}$ & $\begin{array}{l}\text { June } \\
2005\end{array}$ & Total \\
\hline & $\delta / q$ & $3 / 9$ & $\delta / q+$ & $3 / 9$ & $\delta / 9$ & $\delta / 9$ \\
\hline Lutzomyia barrettoi majuscula & $1 / 2$ & $-/ 1$ & $2 / 1$ & $-/ 3$ & $1 /-$ & $4 / 7$ \\
\hline Subgenus Helcocyrtomyia & $-/-$ & $1 /-$ & $-/-$ & $-/-$ & $-/-$ & $1 / 0$ \\
\hline Subgenus Nyssomyia & $-/ 1$ & $1 / 3$ & $-/-$ & $-/-$ & $-/-$ & $1 / 4$ \\
\hline Subgenus Psathyromyia & $-/-$ & $-/-$ & $-/-$ & $-/ 1$ & $-/-$ & $0 / 1$ \\
\hline Lutzomyia spp & $-/ 1$ & $-/-$ & $2 / 1$ & $-/ 1$ & $-/-$ & $2 / 3$ \\
\hline Total & $1 / 4$ & $2 / 4$ & $4 / 2$ & $-/ 5$ & $1 / 0$ & $8 / 15$ \\
\hline
\end{tabular}

TABLE III

Sand flies collected at El Balsamo and Rosa Grande, Nicaragua, 2003-2004

\begin{tabular}{|c|c|c|c|c|}
\hline & $\begin{array}{l}\text { May } \\
2003\end{array}$ & $\begin{array}{c}\text { July } \\
2003\end{array}$ & $\begin{array}{l}\text { May } \\
2004\end{array}$ & Total \\
\hline & $\delta / q$ & $\delta / q$ & $\delta / 9$ & $\delta / 9$ \\
\hline Lutzomyia cruciata & $4 / 1$ & $-/ 1$ & $-/ 2$ & $4 / 4$ \\
\hline Lutzomyia panamensis & $-/-$ & $2 / 1$ & $-/ 1$ & $2 / 1$ \\
\hline Lutzomyia shannoni & $-/-$ & $1 /-$ & $-/-$ & $1 / 0$ \\
\hline Group Cruciata & $-/ 6$ & $-/-$ & $-/-$ & $0 / 6$ \\
\hline Group Vespertilionsis & $-/-$ & $-/ 1$ & $-/-$ & $0 / 1$ \\
\hline Subgenus Psychodopygus & $-/-$ & $-/ 1$ & $-/-$ & $0 / 1$ \\
\hline Lutzomyia spp & $-/ 1$ & $2 / 3$ & $-/-$ & $2 / 4$ \\
\hline Total & $4 / 8$ & $2 / 5$ & $0 / 3$ & $9 / 17$ \\
\hline
\end{tabular}

